\title{
Makt- og kjønnsperspektiver knyttet til bruk av IKT i barnehagen $^{1}$
}

How can power and gender perspectives on using ICT in kindergartens be addressed and understood? This article tries to answer this question by analyzing two cases from Norwegian kindergartens. The writer uses aspects on power from Machiavelli, Weber and Foucault, and recent research on ICT and gender. Machiavellian strategies on being sly rather than fierce were pointed out in both cases and some gender stereotypes as well. Shortage of digital tools in kindergartens seems to contribute to maintain gender stereotypes and sustain unwanted effects of power relations.

SveIn SANDo, f. 1951, førsteamanuensis Dronning Mauds Minne Høgskole for barnehagelererutdanning Thrond Nergaardsveg 7, 7044 Trondheim E-post:ses@dmmh.no

Keywords: Gender, power, Kindergarten, children, ICT, intersectionality

Hvordan kan man synliggjøre og forstå makt- og kjønnsperspektiver knyttet til bruk av IKT i barnehagen? Spørsmålet søkes besvart $i$ denne artikkelen ved å belyse to caser fra barnehager som bruker IKT, med maktaspekter hentet fra Machiavelli, Weber og Foucault, og nyere forskning på kjønn og IKT. Machiavelliske strategier om å vaere listig framfor voldsom ble påvist $i$ begge casene, og kjønnsstereotyper i noen grad også. Knapphet på digitale verktøy $i$ barnehagen synes å bidra både til at kjønnsstereotyper sementeres og at uønskede virkninger av maktrelasjoner opprettholdes.

\section{INNLEDNING}

Det er mange måter å begrunne at makt og kjønn er viktige temaer når IKT og barnehagen drøftes fra et etisk ståsted. Forenklet kan man si at makt og etikk henger på det nøyeste sammen, siden etikk blant annet er refleksjoner om handlinger eller deres konsekvenser er moralsk holdbare i forhold til en eller annen norm. Makt viser seg i handling. Gjør den ikke det dersom den etisk sett burde det, så er makten blitt til avmakt. Drøftinger av makt og maktens virkninger er derfor i mangt også en etisk drøfting.

Når makt så skal forstås i sammenheng med IKT, gjør ikke det maktaspektet mindre relevant, siden IKT er en svært potent og revolusjonerende teknologi siden anvendelsen av den brer seg til stadig flere og flere områder i både privatlivet og samfunnslivet. IKT-etikeren James H. Moor bruker uttrykket «logically mal-

\footnotetext{
1 Artikkelen er en revidert versjon av min prøveforelesning for graden Ph.D. ved Det teologiske Menighetsfakultet den 9. mai 2014. Oppgitt emne var «Makt- og kjønnsperspektiver på bruk av IKT i barnehagen». Avhandlingen har tittelen «Barn, IKT og etikk. En studie i digital etisk dannelse, med norske barnehager som case.» Bedømmelseskomiteen bestod av prof. Dr. Svend Andersen, Århus, prof. Dr. Helje Kringlebotn Sødal, Kristiansand og prof. Dr. Kjetil Fretheim, Oslo.
} 
leable» (logisk smibar) om denne egenskapen ved IKT (Moor, 2004, s. 23). IKT er distribuert globalt og på tvers av nesten alle skillelinjer, også helt ned til de yngste, og altså til barnehagen, der barn etter myndighetenes mening «bør få oppleve at digitale verktøy kan være en kilde til lek, kommunikasjon og innhenting av kunnskap» (Rammeplan for barnehagen, 2006, s. 21). Teknologi og kjønn berøres indirekte i Rammeplanen for barnehagen: «Gutter og jenter skal ha like muligheter til å bli sett og hørt og oppmuntres til å delta i felleskap i alle aktiviteter i barnehagen» (Rammeplan for barnehagen, 2006, s. 10).

Hva makter barna med denne teknologien? Eller hvordan påvirkes barna av å bruke IKT? Bruker jenter og gutter IKT på forskjellig måte slik at det gjør noe med forholdet mellom kjønnene i barnehagen - og senere i livet? Vil disse såkalte «digital natives » som i dag vokser opp med IKT rundt seg på alle kanter, få et annet forhold til IKT som voksen enn slik det er for dagens godt voksne?

Tall fra Statistisk Sentralbyrå viser nemlig at andelen av kvinner som tar høyere utdanning i Norge har ligget på om lag $60 \%$ i over ti år. ${ }^{2}$ Denne høye andelen med kvinner i høyere utdanning har imidlertid ikke slått til med hensyn til å studere IT-fag. Etter noen års oppsving i kvinneinteressen for IT-fag ( «computer science») mellom 1972 og 1984, falt den ned til om lag 17 \% (Corneliussen, 2012, s. 57), og har blitt der siden (OECD-tall). ${ }^{3}$ Dette er en internasjonal trend.

På samme måte som man har forsøkt å få jenter til å studere datafag, og ikke lykkes særlig med det, så har man i omtrent like liten grad lykkes med å få gutter til å bli barnehagelærere. Vil det at IKT er på vei inn i barnehagehverdagen medføre noe endring med disse mer langsiktige tingene? Vil det for eksempel bli flere kvinner som deltar aktivt i utviklingen av IKT, og vil det bli flere gutter som velger å jobbe i barnehagen fordi det er blitt ikke bare legitimt, men ønsket, at IKT skal brukes i barnehagehverdagen?

Dette leder fram til den problemstillingen jeg vil forsøke å gi tilløp til et svar på:

Hvordan kan man synliggjøre og forstå makt- og kjønnsperspektiver ved bruk av IKT i barnehagen, og hvordan kan eventuelle digitale skiller $i$ barnehagen motvirkes?

Jeg drøfter i det følgende både aspekter ved makt, og hva som er forholdet mellom kjønn og IKT i den etiske diskursen. Jeg henter fram noe av den siste forskningen som gjort på barnehagebarn og IKT, hvilket er svært lite. Derfor har jeg valgt å hente fram stoff fra egne observasjoner fra barnehagen i forbindelse med mitt doktorgradsarbeid, og har underlagt det stoffet en makt- og kjønnsvinkling for å gi konkrete eksempler på makt og kjønnsanalyser i barnehagen. Til slutt diskuterer jeg hva dette bør føre til av praktiske tiltak i en barnehagehverdag.

\section{TRE ASPEKTER PÅ MAKT}

For å belyse maktforholdene rundt IKT og barn anvender jeg en enkel maktmodell med bidrag fra Machiavelli, Weber og Foucault.

\section{Machiavelli}

Florentineren Niccolo Machiavelli (14691527) skrev boka Fyrsten antagelig i 1513. Der er makten noe som er knyttet til fyrsten som den øverste i samfunnshierarkiet. Boka er en beskrivelse av tingenes tilstand mer enn norm for hvordan det bør være. Fyrsten må bruke makt fordi det duger ikke med mindre:

2 http://www.ssb.no/utdanning/statistikker/utuvh/aar

3 I følge OECD-tall har antall ferdigutdannede kvinner i "computing” i Norge på høyere nivå ("Tertiary-type A and advanced research programmes") mellom 1998 og 2011 variert mellom 4 og $21 \%$ årlig, med en gjennomsnitt på 17,8 \%. 
Det finnes to måter å kjempe på: med lov og med makt. Lovens vei er menneskenes kampform, makten er dyrenes. Men da den første ofte viser seg utilstrekkelig, er det nødvendig å ty til den andre. Derfor må fyrsten vite å kunne vere såvel [!] dyr som menneske

(Machiavelli \& Bingen, 1998, s. 91).

Og hvilke dyr? Jo, løven og reven. Den ene representerer rå og brutal makt, reven den listige:

Den har lyktes mest, som best har visst å benytte seg av revens egenskaper. Det viktige er å kunne forskjønne en slik opptreden og vise dyktighet $i$ sitt hykleri og sin forstillelse. Så enkle er menneskene, og $i$ den grad adlyder de dagens bud at den som onsker å fare med lureri alltid vil finne noen som lar seg lure (Machiavelli \& Bingen, 1998, s. 92).

Ved å henvise til revens list, beskrev Machiavelli at makt utøves på flere måter enn med vold (løven). Makt kan utøves i en rekke relasjoner, og den kan utøves skjult og indirekte.

\section{Weber}

Sosiologen Karl Emil Maximilian Weber (18641920) beskriver makt på individnivå. Det handlende individet utøver makt ved å tvinge igjennom sin vilje med de midler en har til rådighet: «Ved makt vil vi her allment forstå et eller flere menneskers sjanse til å sette gjennom sin egen vilje i det sosiale samkvem, og det selv om andre deltakere i det kollektive liv skulle gjøre motstand» (Weber, 1922/1994, s. 53).

Weber knytter altså makt til det som skjer i relasjoner mellom mennesker. Selv om han sier at noen kan gjøre motstand mot denne viljen som vil sette noe gjennom, så er ikke motstanden nødvendig for at det skal kunne kalles makt. Man kan godt tenke seg at noen argumenterer så godt for det man vil, at andre blir enige. Også da er det snakk om maktutøvelse.
Eller man kan tenke seg at man vurderer at det får for store omkostninger å gå imot viljen, og slik sett aldri setter i gang noen uttalt motstand.

Etisk sett er det derfor ikke nødvendig at det skal være en motstand mot noe for at viljen til handling skal kunne bedømmes som etisk uforsvarlig eller illegitim. Pliktetisk må man kunne vurdere de handlinger som makten iverksetter, og konsekvensetisk må man kunne vurdere effekten av det man med sin vilje setter gjennom i «sosiale samkvem», for å bruke Webers formulering.

\section{Foucault}

Michel Foucault (1926-1984) er mer opptatt av hvordan makt utøves, enn i makten selv. Det er maktens relasjoner som er interessant:

The exercise of power is not simply a relationship between partners, individual or collective; it is a way in which certain actions modify others. Which is to say, of course, that something called Power, with or without a capital letter, which is assumed to exist universally in concentrated or diffused form, does not exist

(Foucault, 1982/1983, s. 219).

Makt beskrives her som påvirkning av andre personer, mens makt som noe som eksisterer i seg selv avvises. Når makten utøves, manifesterer den seg: «'How,' not in the sense of 'How does it manifest itself?' but 'By what means is it exercised?' and 'What happens when individuals exert (as they say) power over others?'» (Foucault, 1982/1983, s. 217)

Det er altså handlingens virkning som er interessant. Metodisk knytter Foucault dette til det han samme sted kaller «the little question, What happens» (s. 217)? Hva er det som skjer i relasjonen mellom mennesker? Hvilke handlinger mellom dem er det som påvirker slik at det skjer en endring? Der er maktutøvelsen. 
En enkel maktmodell

Fra Machiavelli henter jeg den listige (reven) som oppnår mer enn den brutale (løven). Machiavelli sier noe om hvordan makten best gjennomføres. Fra Weber bruker jeg at makt er evnen til å få viljen sin. Fra Foucault tar jeg poenget om at makten ikke finnes i seg selv, men bare når den manifesterer seg i relasjoner mellom aktører. Idet makten manifesterer seg, kan den også underlegges etisk refleksjon. Modellen kan illustreres slik særlig med tanke på Webers og Foucaults bidrag:

FIGUR 1

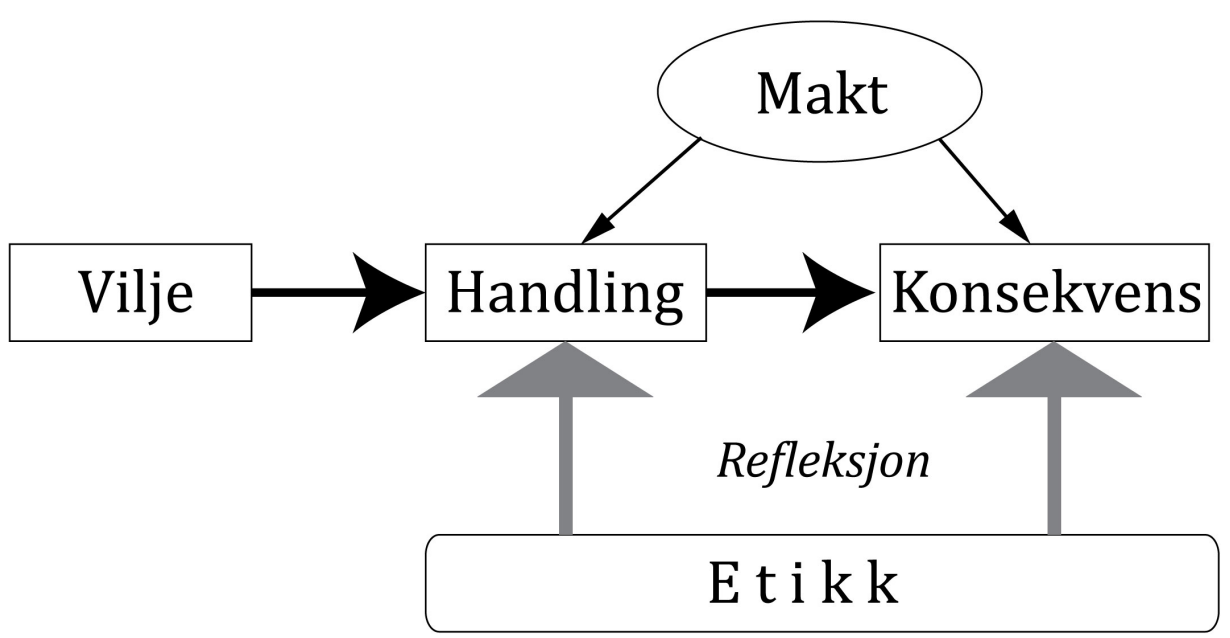

KJØNN

Den fagetiske diskursen om IKT og kjønn vil jeg nærme meg via generell feministisk etikk.

\section{Gilligan}

Psykologen og pedagogen Carol Gilligan regnes ofte som grunnleggeren av feministisk etikk, i Gilligans versjon gjerne benevnt som «ethics of care» (Ess, 2009, s. 202). Gilligans kanoniske verk fra 1982 (Adam, 2008, s. 591) er In a Different Voice (Gilligan, 1982), i norsk utgave Med en annen stemme (Gilligan, 1982/2002). Hun kritiserte Lawrence Kohlbergs teori om etisk utvikling for å ha brukt utelukkende gutter i sine empiriske undersøkelser. Når hun stilte de samme spørsmålene til jenter, fikk hun andre svar, som førte til en annen utviklingsmodell for kvinner enn det Kohlberg fant for menn. Når kvinner ble stilt overfor de samme etiske dilemmaene som Kohlberg stilte menn overfor, fant hun at de brukte flere vurderingsaspekter enn menn. Mens menn la vekt på etiske prinsipper som rettferdighet o.l., trakk kvinnene i tillegg inn emosjonelle og relasjonelle aspekter.

\section{Ess}

Medieviteren og filosofen Charles Ess ser en fare ved feministisk etikk ved at den kan forstås som essensialistisk ved at denne evnen til å benytte seg av følelser og relasjoner er knyttet til biologien. Man kan komme til å fokusere på hva kvinner føler i motsetning til hvordan menn tenker (Ess, 2009, s. 211). I tilfelle vil dette bare støtte opp under kjønnsstereotyper som feminismen ellers vil overvinne. Ess gir imidlertid argumenter selv for at dette ikke trenger å forstås essensialistisk, 
ved å henvise til blant annet David Hume, som nettopp la vekt på emosjoner som fundamentale for etisk refleksjon, og til det aristoteliske fronesis-begrep, «a practical ethical judgment that is felt as much as thought $\gg$ (Ess, 2009, s. 204).

Ess gir et par eksempler på IKT-etiske anvendelser av feministisk etikk. Det ene er bruk av mobiltelefon til «just to say 'hi' » (s. 204), med hensikt å styrke relasjonen mellom folk. Det andre eksemplet er hvordan man på blant annet sosiale medier kan dele og spre sanger, videoklipp, for «sharing is caring $»$ (s. 204).

\section{Adam}

Det er kanskje denne type ganske magre konsekvenser av en feministisk etikk som Ess nevner som den britiske professor Alison Adam har i tankene, når hun i 2008 skriver at den fagetiske diskursen om kjønn og IKT er mager, spriker, har liten kontakt med hverandres arbeider og er underteoretisert med hensyn til både etikk og kjønn. Dette passer bra med det Eva Turner skriver om å undervise i IKT-etikk for IT-personell. Kjønnsperspektivet er nesten helt fraværende, og finnes den i fagdiskursen, så er det nesten bare ved at kvinner ses på som ofre (Turner, 2006). Det er helt beslektet med den observasjonen jeg har gjort i min avhandling når det gjelder barn i IKT-etikkdiskursen, som nesten bare opptrer som ofre (Sando, 2014, s. 10).

Alison Adam synes å være en av de få som over en periode har behandlet kjønnsperspektivet ved IKT-etikk mer spesifikt (Adam, 2000, $2005,2008,2010)$. Hun er opptatt av metodologien ved forskningen omkring kjønn og IKT, og mener at tradisjonelle metoder med spørreskjema og avhuking er lite egnet til å avdekke kjønnsrelaterte aspekter fordi disse ofte er skjult og sjelden fanges opp av forhåndsstilte spørsmål. Hun anbefaler derfor heller grounded theory eller etnografiske studier der man er mye tettere på forskningsobjektet.
I kapittel $9 \mathrm{i}$ The Cambridge Handbook of Information and Computer Ethics (Adam, 2010), drøfter Adam utopier som oppstod på 1990-tallet om at Internett skulle føre til det kjønnsegalitære samfunnet, og den enda mer kvinneoptimistiske tanken om «cyberfeminism».

Tron Øgrim sto for slike utopier i boka Hilsen til en generasjon av kvikksølv! (Øgrim, 1997) der han spådde om hvordan Norge blir i 2014 på IKT-området. Jenter vil da være på full fart inn i akademia og vil overta hegemoniet om noen år. Det fikk han rett i. Siden informasjonsteknologi kommer til å handle mindre om «bokser» og mer om å bruke dem, vil jenter overta, fordi nå handler det mer om å bruke Internett enn om hvordan det er skrudd sammen, spådde Øgrim (ss. 114-115).

Adam mener slike utopier ikke har slått til fordi de bygger på et teknologideterministisk syn. Det vil si at teknologien er etisk, kulturelt og politisk nøytral. Adams sier at «it ignores the ways that social relations are already designed into technologies $\gg$ (Adam, 2010, s. 157).

Langdon Winner avviste allerede i 1980 teknologideterminismen med sin klassiske teknologihistoriske artikkel «Do artefacts have politics?» (Winner, 1980). Som et eksempel viste han at omtrent 200 brounderganger langs strandområdene på Long Island ble bygget på 1920-tallet med hensikt så lave at busser ikke kunne kjøre under dem. Dermed ble lavinntektsgruppene som ikke hadde råd til egen bil, holdt utenfor dette attraktive området.

Men hvis «artefacts have politics», da kan også «computers have politics». Hva er i tilfelle det? Vi kan hente ut noen slike fra den allerede nevnte boka til Tron Øgrim fra 1997 (s. 106):

- Vi [veit] at data er gutters leketøy.

- Data har vært ingeniør-guttas sandkasse.

- Internett ER ennå mest leiketøy ... Og DYRT leiketøy. Foreldre kjøper DYRERE og mer TEKNISK leiketøy til Petter enn til Petra. 
Dette er eksempler på stereotyper knyttet til kjønn og IKT, som vi skal se nærmere på.

\section{Kjonnsstereotyper}

Medieviteren Steven Kirsh forstår med begrepet stereotype 4 dette:

Stereotypes are generalized and/or assumed conceptualizations about a group or individuals.... stereotypes relay a simplified view of others that typically centers on a limited number of characteristics. [...] Once created, stereotypes are thought to be resistant to change (Kirsh, 2010, s. 103-104).

Stereotypene generaliserer over store grupper ved å hefte et lite antall karakteristika ved alle i gruppen, og stereotypene er vanskelig å rokke ved. Slik sett fungerer de normativt som «sannheter» og skaper både fordommer og forventninger overfor dem som hører med til gruppen. Og er en selv i gruppen, kan derfor stereotypene virke normerende på en selv: Slik må jeg være eller bli. Etisk sett fungerer altså stereotyper som normer som påvirker både holdninger og handlinger. Det ligger maktpotensiale i stereotypene, ut fra Foucaults perspektiv.

I fagdiskursen om IKT fant jeg disse kjønnsstereotypene nevnt:

- Menn tenker, kvinner føler (Ess, 2009, s. 211)

- Menn har velutviklet moralsk sans, noe kvinner ikke har (Freud) (Adam, 2008, s. 591)

- Kvinner er mindre dyktige på teknologi enn det menn er (Adam, 2008, s. 600)

- Datamaskinen er gutters leketøy (Corneliussen, 2012, s. 9)

\section{Interseksjonalitet}

Innen sosiologien, og særlig kjønnsforskningen, har interseksjonalitet de siste tiårene blitt brukt som et analytisk rammeverk, teori eller metafor for å forstå komplekse årsaksforhold og prosesser. Metaforen skal ha bredt seg til andre fagdisipliner i forbindelse med tverrfaglige prosjekter (Collins \& Chepp, 2013, s. 57). Metaforen er hentet fra engelsk intersection' og skal ifølge professor Toril Moi (Bergstrøm, 2014) ${ }^{5}$ ha blitt lansert av jusprofessor ved UCLA Kimberlé Crenshaw i essayet «Demarginalizing the Intersection of Race and Sex: A Black Feminist Critique of Antidiscrimination Doctrine, Feminist Theory and Antiracist Politics» (1989). Crenshaw bruker dette som en metafor for å motvirke «the tendency to treat race and gender as mutually exclusive categories of experience and analysis $\gg$ (1989, s. 139) og for å vise ulempen ved å tenke «along a single categorical axis» (1989, s. 140). I den norske litteraturen oversettes 'intersection' gjerne med 'veikryss' (Orupabo, 2014, s. 329). Hva interseksjonalitet egentlig er, er mye debattert og kritisert. Kathy Davis betrakter 'intersectionality' som et moteord (buzzword) (Davis, 2011, s. 43). Toril Moi mener det er overteoretisert og for mange ganske uforståelig (Bergstrøm, 2014). Den positive meningen er at metaforen skal hjelpe forskeren til å tenke på tvers av kategorier (Davis, 2011, s. 49), en annen at metaforen skal problematisere binære eller dikotome forklaringer og synspunkter, og dermed åpne for synspunkter for at makt interagerer på komplekse måter (Collins \& Chepp, 2013, ss. 61-62).

4 Selve begrepene klisje og stereotype kommer fra boktrykkerfaget der de er synonymer for at en kopi av en tekst eller bilde er støpt i en fast form, og dette avtrykket brukes så i selve trykkingen til å lage mange eksakt like kopier. Begge begrepene er for lengst blitt tatt i bruk i overført betydning, for eksempel uttrykt slik: «(psykol.) det (forenklede, klisjéaktige) bilde man danner seg av en gruppe mennesker; fordom [avl. av stereotypi] $\gg$ (Store norske ordbok, 1991, s. 574).

5 Mois foredrag foreligger i skrivende stund bare som omtale i Kilden, men skal publiseres i New Literary History. 
Interseksjonalitet kan med fordel brukes sammen med Foucaults maktforståelse om at makten utøves i relasjonene, ved å hjelpe oss å lete etter flerdimensjonale maktrelasjoner og makthandlinger som kan manifestere seg på ganske kompleks måte, som jeg vil vise senere i artikkelen.

\section{FORSKNING PÅ MAKT, KJØNN, IKT OG BARN}

Det er ganske sparsomt med forskning på makt og kjønn, barnehagebarn og IKT. Det aller meste er gjort på større barn, men noe kan trekkes fram:

Medietilsynets undersøkelse fra april 2014 Foreldre om småbarns mediebruk (Medietilsynet, 2014) viser at dataspilling er en utbredt aktivitet også blant de yngste. $16 \%$ av 1-4-åringene spiller dataspill daglig, og $48 \%$ spiller minst ukentlig. For 5-8-åringene er andelen som spiller minst ukentlig, hele $84 \%$ (s. 37). Det er en viss forskjell på gutter og jenter i hvor mye de spiller, i den retningen at gutter spiller noe mer. For hele aldersgruppen 1-12 år spiller $48 \%$ av guttene minst én gang om dagen, mens det samme tallet for jenter er $36 \%$. Men når det gjelder bruk av Internett, så ligger jentene litt foran i mengde for hele aldersgruppen 1-12 år (s. 28). Dessverre er ikke tabellene publisert slik at vi kan se på barnehagealderen spesielt, og samtidig få se om det er kjønnsforskjeller. Uansett viser disse tallene fra Medietilsynet at stereotypen om at datamaskiner er gutters leketøy, ikke stemmer helt med virkeligheten, i hvert fall ikke blant 1-12-åringene i Norge i 2014.

Steven Kirsh har i boka Media and Youth, a developmental perspective, fra 2010, gått gjennom en rekke forskningsrapporter for å se på hva slags stereotyper som nettopp finnes i dataspill. Hans funn gjelder ikke bare spill egnet for de yngste barna, men mer generelt. Det han finner er at jenter og kvinner i dataspillene i hovedsak framstilles som kulisser, tilskuere, kvinner i nød eller voldsofre. De følger også stereotypene ved at de dobbelt så ofte som menn er villige til å dele på godene, og fire ganger så ofte framstår kvinner som hjelpere eller oppdragere. I den grad figurer opptrer utenfor stereotypene, er det kvinner som tar på seg maskuline trekk, ikke omvendt. Menn forblir aggressive og voldelige (Kirsh, 2010, s. 119).

Kirsh spør også etter hva effekten er av disse klisjeene i dataspill og andre medier som barn og unge bruker. Han finner på det tidspunktet han skriver at det ikke er gjort noen studier for førskolegruppen når det gjelder kjønnsstereotyper. For de eldre barna finnes det noe, men funnene er lite entydige og gir i beste fall bare en svak indikasjon om stereotypene faktisk påvirker barna og ungdommen. «Much more research is needed to provide a convincing argument that stereotyped media content influences modern youth» (Kirsh, 2010, s. 121). Dette tilsvarer et lignende funn vedrørende forskningen om det er noen sammenheng mellom voldsspill og aggressiv atferd. Forskningen spriker (Feilitzen, 2010, s. 180) eller er fortsatt ikke kommet langt nok (Hartmann, 2013, s. 125).

Agneta Ljung-Djärf disputerte i 2004 på avhandlingen Spelet rundt datorn. Datoranvändande som meningsskapande praktik i förskolan. I en av artiklene beskriver hun det som er et maktaspekt mellom barna og datamaskinen, som igjen påvirker mulige maktrelasjoner mellom flere av barna:

I analysen av barns samvaro runt datorn har tre positioner definierats. Dessa utgör en hierarki i relation till datorns mus och tangentbord. Datorns konstruktion tilldelar den som kontrollerar musen positionen som huvudanvändare, [...] vilket innebär ett övertag gentemot övriga. (Ljung-Djärf, 2004, s. 157)

Jeg skal senere vise et eksempel på dette, men også utvide analysen. 
Medieviteren Elise Seip Tønnesen gir i kapittel 7 i sin bok Generasjon.com. Mediekultur blant barn og unge (Tønnessen, 2007) et innsiktsfullt bilde av kjønnsforskjeller hos barn og unge knyttet særlig til dataspill. Svakheten, fra mitt synspunkt her, er at hun til tross for at hun signaliserer at hun har materiale til å se på hvordan mediepreferansene «utvikler seg over tid fra barnehagealder og ut grunnskolen» (s. 133), dessverre bare drøfter det hun har funnet om de eldste barna. Konklusjonen hennes er at det på dataspillenes område er «ekstreme forskjeller på gutter og jenters praksis og preferanser» (s. 133). Dette utdypes nærmere som at

Mens guttene tiltrekkes av det som krever teknisk kompetanse, hurtighet og målrettethet, fascineres jentene av det som appellerer til det kreative og estetiske, og som utfolder seg over tid, der prosessen er viktigere enn produktet. (Tønnessen, 2007, s. 152)

Hun skriver dette i 2007, og materialet hennes spenner over perioden 1993 til 2005 (s. 12f). Medietilsynets undersøkelse fra 2014 viser at $90 \%$ av både gutter og jenter er dataspillere, men støtter Tønnesens funn om ulike preferanser hva spilltyper angår. Gutter spiller Lego, Super Mario, FIFA og Clash of Clans, sier undersøkelsen, mens jenter spiller Josefine, SIMS og Moviestarplanet (Medietilsynet, 2014, s. 11).

Av nyere internasjonale artikler som forsker på førskolegruppen, er det noen som viser at det ikke er signifikante forskjeller mellom kjønnene i forhold til IKT verken med hensyn til adgang til og bruk av IKT (Hardersen \& Guðmundsdottir, 2012), til basiskunnskaper i IKT (McKenney \& Voogt, 2010; Sackes, Trundle, \& Bell, 2011) eller kreativ tenkning (Aseel, 2011). Små forskjeller ble funnet med hensyn til å utvikle sine IKT-ferdigheter der jenter hadde en raskere utvikling (Sackes, et al., 2011), mens gutter hadde mer positive holdninger til datamaskinen for sin egen del (McKenney \& Voogt, 2010). Når det gjelder valg av IKT-aktiviteter, viser en gresk studie at omtrent dobbelt så mange gutter (55\%) velger konsollspill framfor hva jenter (26\%) gjør (Nikolopoulou, Gialamas, \& Batsouta, 2010, s. 33).

Av disse er det bare den greske undersøkelsen som i noen grad bekrefter en av de nevnte kjønnsstereotypene, nemlig den om at datamaskinen er gutters leketøy. Men den gjør det bare i den forstand at det bare er ved dataspilling at datamaskinen betraktes som leketøy. Samme greske studie viser at jenter i større grad enn gutter velger å bruke kreative tegneprogrammer.

\section{EGET MATERIALE}

Jeg vil ta med meg disse synspunktene i en tolkning av materialet fra egne observasjoner jeg gjorde i 2009/10 i åtte ulike barnehager i Trøndelag. Observasjonene resulterte i ni timer med videoopptak der barn bruker IKT (Sando, 2014, ss. 75-88). Jeg har særlig sett med Foucaults blikk etter de små fortellingene om «hva skjer?» og «hva avstedbringer det?». Jeg har også sett etter om, og på hvilken måte, kjønnsstereotypene og kjønnsbeskrivelsene som jeg har presentert, lar seg gjenfinne i observasjonene.

Ni timer observasjon er altfor lite å gjøre gode kvantitative analyser på, men det var umulig å ikke legge merke til hvor dominerende guttene var i de øktene der begge kjønn hadde anledning til å delta. Fordeling var slik, regnet ut fra antall minutter de ulike kjønnene var førende i å bruke et digitalt medium, som i de fleste tilfellene var en datamaskin:

Tabell 1

\begin{tabular}{|l|c|c|}
\cline { 2 - 3 } \multicolumn{1}{c|}{} & T:min & $\%$ \\
\hline Gutter dominerte & $3: 00$ & 53 \\
\hline Balanse mellom kjønnene & $1: 59$ & 35 \\
\hline Jenter dominerte & $0: 20$ & 6 \\
\hline Uklart & $0: 12$ & 4 \\
\hline
\end{tabular}


Dette leder over til en praktisk forutsetning for at det i det hele tatt gikk an å lage en slik oversikt over dominans, nemlig det ressursmessige forhold i barnehagene at det digitale verktøyet oftest er et knapphetsgode, med typisk 1-2 datamaskiner i hver avdeling, og at datamaskiner inntil nylig er konstruert som enbrukermaskiner med ett tastatur og én mus. De nye touchskjermene som kom med smarttelefonene og nettbrettene, åpner for en annen type bruk i så måte. I mine observasjoner var det enda tastatur og mus som gjaldt.

\section{«Arne og Espen»}

Arne og Espen (fiktive navn) spiller et av Josefinespillene. Dette er et spill som i Medietilsynets rapport for øvrig ble klassifisert som et jentespill (Medietilsynet, 2014, s. 11).

Guttene er jevngamle, men Arne er den som for det meste har kontroll over mus og tastatur. Han er «musefører» og bestemmer hvordan spillet skal gjennomføres rent praktisk. Arne har tilsynelatende et visst maktovertak i spillet. Men Espen vil gjerne være musefører også. Første gang de bytter, er det fordi Arne må på toalettet. Følgende replikkveksling utspiller seg:

- Arne: «Æ må på do!»

- Espen: «Er det min tur no?»

- Arne: «Du kan spill imens æ går på do.»

- Espen: «Okey!» $[\mathrm{K} \# 596-599]^{6}$

Makthierarkiet er tydelig. Arne styrer, og Espen underkaster seg. Arne overlater musestyringen til Espen når han er fraværende selv, men bare da. Espen aksepterer med «Okey». Agneta Ljung-Djärf beskriver en beslektet situasjon i sin avhandling, og sier at datamaskinen dermed skaper et hierarki mellom musefører og tilskuere (Ljung-Djärf, 2004, s. 157).

Seks minutter senere er Espen mer frampå, og spør «Når er det min tur? », men Arne mum- ler noe uforståelig som svar og beholder musa. Espen vil tydeligvis være mer delaktig i spillet, og siden han ikke får styre musa selv, begynner han å fortelle Arne hva de bør gjøre i spillet. Til å begynne med går det helst på overordnede ting, som hvilket rom i spillet de skal gå inn i, men etter hvert også mer detaljert og instruerende: «No kjem den! Trykk» [K\#649]!

Fire minutter senere, etter 20 minutters spilling til sammen, har lysten hos Espen til å være musefører økt enda mer, og han gjør gjentatte forsøk med «Nå er det min tur!», med både høy stemme og lav stemme, uten at det virker. Men Arne skjønner at han må gi noe tilbake, og prøver seg med: «Vil du velg ka æx ska hold på med $\gg[\mathrm{K} \# 677]$ ?

Espen godtar det, men de kommer straks i krangel om hvor i spillet de skal. To minutter senere spør Espen igjen om ikke det er hans tur til å overta musa. Denne gangen gir Arne seg, men med betingelsen: «Ja. ... Og etterpå er det min tur igjen, ikke sant» [K\#690]. Denne siste forhandlingsrunden varte i tre og et halvt minutt før Espen endelig overtok musa, og da hadde de spilt i 24 minutter tilsammen.

Fem minutter senere er de inne i et rom der man skal kjøre snowboard, hvilket krever at man behersker mus eller tastatur bra, og det er ikke Espen så god til som Arne. Etter et par forsøk gir Espen seg og gir musa frivillig til Arne med replikken «Kan ikke du prøve» [K\#701] Bedre motorisk datakompetanse gir altså i dette tilfelle tilgang til å gjenvinne makten over musa.

Deretter beholder Arne musemakten resten av spillet, som varer 1 time og 15 minutter til! Espen kompenserer imidlertid ved å gi instruksjoner om hva de skal gjøre på spillet, og Arne følger stort sett disse. Det utvikler seg altså en slags maktbalanse ved at Arne utfører, men Espen dirigerer Arne dersom Espen synes

6 Henvisning til observasjonsøkt (barnehage) og linje i transkripsjonene. 
Arne velger feil. Mot slutten av spillet mestrer de å komme til en løsning på en oppgave i spillet de ikke har fått til tidligere, og dette blir de så glade for at de løper ut til resten av barna på avdelingen og forteller begeistret om sin bragd. Barnehagestyreren hører dette, og spør guttene: «Samarbeida dere, eller» [K\#782]? Arne svarte bekreftende på det.

Maktforhandlingene som denne observasjonen illustrerer, har altså delvis sin forutsetning $\mathrm{i}$ at to personer bruker et dataspill som teknisk sett er beregnet for én person. Dermed må man dele på en felles ressurs, men bare én kan være faktisk utøver. Praktisk ferdighet med å bruke mus og tastatur viser seg i denne fortellingen som årsaken til at den ene faktisk ble overlatt makten over musa av den andre. Et felles mål om å klare oppgavene best mulig lå antagelig til grunn for det som skjedde. Selv om starten på denne observasjonen viser at det var et visst maktspill om å være musefører, klarte de likevel å finne et praktisk godt samspill slik at begge to fant dette som en meningsfull aktivitet de kunne ha glede av i nesten to timer. De forhandlet underveis, men kom etter en halv times tid til en balanse der den ene utførte og den andre instruerte. Ulempen for Espen med tanke på senere spill, var at Espen ikke fikk særlig anledning til å bedre sin motoriske ferdighet med å bruke mus og tastatur. Balansen de kom fram til, sementerte således denne kompetanseforskjellen, men det var bra for samspillet mellom dem der og da. For de samarbeidet faktisk.

\section{«Mikkel» (Rev) og jentene}

Situasjonen er en barnehageavdeling med én PC som barna bruker til å være på Internett med, via Telenor sin barneside. Hele økta varte i 47 minutter. I 36 minutter var det én og samme gutt som var musefører. Vi kaller ham Mikkel. De siste 11 minuttene overtok - en annen gutt. Jentene framstod som tilskuere gjennom hele økta til det som skjedde på skjermen.

Likevel hadde de andre barna faktisk innflytelse over det som skulle gjøres, blant annet godt tilrettelagt av Mikkel som var god til å være i dialog med de andre barna. Mikkel ledet det hele på en fin måte, ved for eksempel å spørre hvem som vil være hvilke figurer i spillene. I det hele framsto Mikkel, kun 4 år, som en ledertype som på tilsynelatende demokratisk vis ledet til beste for de andre. De filmsnuttene de sammen så på, syntes å være interessante for jentene som stod rundt maskinen også. De hadde felles glede av det de så på, og alle var med på å kommentere det de så. Det var ingen kjønnsforskjell å se, bortsett fra det åpenbare at det var en gutt som var musefører hele tiden.

Mikkel la til rette og var lydhør først og fremst for andres ønsker. Samtidig vernet han om maskinen slik at ingen andre fikk røre maskinen mens spillet pågikk. Aner vi her en slags dobbel agenda, der primærmålet hans var å få bruke tastatur og mus, mens hva han brukte det til, var sekundært? For at hans plass i førersetet skulle være legitim, måtte han også gi noe tilbake til de andre, og det å spørre de andre om hva de ville gjøre, var da en slags betaling for å beholde musemakten. Han brukte ikke fysisk makt, selv om han faktisk beholdt musemakten, men han brukte metoder for å beholde makten på som var mer som revens enn løvens, i machiavellisk forstand.

Den tilstedeværende førskolelæreren var ganske passiv. Hun observerte hva som skjedde, men hvorfor fikk Mikkel være musefører alene i 36 minutter? For henne virker det som utfordringen var om nettsidene de var på var egnet for barn, men på forespørsel sa hun at hun støttet seg på at maskinen hadde filter som hindrer slikt.

Det kunne virke som førskolelæreren var usikker på sin rolle som pedagog og som IKTbruker, hvis hun da ikke hadde en tanke om at man skal blande seg minst mulig inn i barnas lek 
og databruk. Men dermed sementeres en del maktstrukturer. Mikkel som tidlig erobret førersetet foran maskinen, fikk bli sittende, til tross for at maskinen var en knapphetsressurs som alle barna på avdelingen måtte dele på. Dermed fikk ingen av de andre barna trening og erfaring med å bruke maskinen. Stereotypen om at datamaskinen er gutters leketøy, ble demonstrert ved førskolelærerens manglende styring. Slik sett kan man si at førskolelæreren viste sin avmakt, mens gutten i førersetet befestet sin maktposisjon. I dette tilfellet brukte imidlertid gutten makten på en tilsynelatende sympatisk måte ved at han slapp til de andre barna med hensyn til hva de skulle gjøre. Han opptrådte nærmest som en drosjesjåfør, som kjørte bilen, men hvor hen det skulle kjøres, bestemte andre. Dermed fikk jentene likevel innflytelse ved å styre på et mer overordnet plan, omtrent som Espen i forrige fortelling også etter hvert styrte Arne.

\section{Personalets blikk for kjonnsforskjeller}

I tre av barnehagene jeg hadde observasjoner, oppdaget jeg kjønnsforskjeller som jeg tok opp med personalet underveis eller i etterkant. De forskjellene jeg oppdaget, ble i to av tilfellene forklart med at det jeg observerte med guttedominans var tilfeldig, og at det var ulike ytre årsaker til at det var blitt slik det ble akkurat når jeg var til stede. I det andre tilfellet ble det forklart med at jentene gjerne valgte andre ting å leke med, men medgikk også at det aspektet hadde man ikke tenkt noe særlig på.

Samlet virket det altså som at kjønnsaspekter i forhold til IKT ikke var tematisert blant personalet i disse tre barnehagene.

\section{KONKLUSJONER}

Observasjonene gir eksempler på hvordan teknologiens faktiske framtoning skaper bruksmønstre som legger opp til en todeling mellom utøver og observatør. Samtidig viser observasjonene at det som man i første omgang kunne forstå som en vinner og en eller flere tapere, ikke uten videre er helt dekkende for slike situasjoner. I begge observasjonene med barna så vi hvordan mangel på teknisk styring av maskinen åpnet for å kunne styre på mer indirekte måter. Espen ble etter hvert den som administrerte Arne, og Mikkel lot de andre barna bestemme hvilke spill eller videoer de skulle se på. Spørsmålet om hvem som hadde makt, ble nesten snudd på hodet.

Men da spør vi etter maktposisjoner, og Foucault har lært oss i stedet å spørre etter effekten av maktutøvelsen(e). Hva er effekten i disse to fortellingene? For Espen og Arne ble resultatet at de løste gåten i spillet, og deres reaksjon med å involvere resten av barnegruppa i den gleden, viste at dette virkelig var en stor seier for dem begge. For Mikkel og jentene (og noen andre gutter også) var effekten at de hadde felles glede av disse spillene og videoene, selv om bare én av dem fikk faktisk bruke mus og tastatur.

Det kunne imidlertid gått annerledes. Arne kunne overhørt Espens instruksjoner, og Mikkel kunne valgt de spillene og videoene som han selv var mest interessert i. Slik sett var disse situasjonene labile. Antagelig var det det styreren hadde som baktanke når han spurte Arne og Espen om de hadde samarbeidet. Det var for ham kanskje lakmustesten på om det var etisk rett å la Arne og Espen spille dataspill alene $\mathrm{i}$ hele to timer.

Men var da alt i sin skjønneste orden i disse to praksisfortellingene slik de faktisk forløp? Jeg har allerede påpekt den ulempen at forskjeller i praktisk dataferdigheter ikke bare ble opprettholdt, men den som allerede kunne mye fra før, fikk trening i å bli enda bedre - det Robert Merton kalte Matteus-effekten (Merton, 1968). Observasjonene mine har eksempler på at både gutter og jenter taper. Skjevheten er ikke i og 
for seg kjønnet, men ting kan tyde på at gutter oftere kommer i slike vinnerposisjoner enn jenter, i hvert fall dersom stereotyper om at gutter er mer besluttsomme, ser datamaskinen som sitt leketøy, er mer aggressive o.l., faktisk har en rot i virkeligheten.

En kvinnelig kollega gjorde meg imidlertid oppmerksom på en annen side av denne saken, og det er barnehagen som kvinnedominert arena. Kanskje guttene i mine observasjoner som flokket seg om datamaskinen, gjorde det fordi dette var en arena de i større grad fant artig, enn andre finmotoriske, feminine aktivitetstyper barnehagene tradisjonelt er så fulle av. Det vil i tilfelle forklare noe av det store spriket som synes å være mellom at gutter i barnehagen virker å dominere IKT-bildet i mye større grad enn utenfor barnehagen. Medietilsynets undersøkelse blant småbarnsforeldre viser nemlig at det er lite kjønnsforskjell på IKT-aktivitetens omfang blant barna i hjemmet. Der er de digitale verktøyene tilgjengelig på en annen og ustrukturert måte, og er ikke et så stort knapphetsgode som i barnehagen.

Digitale klasseskiller, enten de skyldes sosiale og økonomiske forhold, eller kjønn, bør likevel motarbeides på de arenaene der man kan gjøre noe. Barnehagen er en slik arena, siden tilgangen på digitale verktøy faktisk er begrenset så langt. Det betyr at hvem som får være faktisk primærbruker av verktøyene må reguleres, men altså ikke bare etter kjønn stereotypisk forstått, men på individnivå, og etter forutsetninger. $\mathrm{Og}$ for å motvirke den tilsynelatende selvframdrivende Matteus-effekten, må man heller la dem som allerede kan mye og har mye dataerfaring, stille bakerst i køen.

Bruk av interseksjonalitetsmetaforen fra kjønnsforskningen støtter en slik forståelse. Kjønn er ikke den eneste faktoren, men samvirker med andre faktorer. Aktørenes IKTkompetanse er en slik faktor, som i begge disse casenes tilfeller ble brukt til hele gruppas beste. Begge casene hadde en felles strukturell forutsetning som var en helt avgjørende faktor for at maktspillet om musemakten i det hele oppstod, nemlig at datamaskinen var en begrenset ressurs.

Å gi barna en lik ballast av digitale ferdigheter og digitale erfaringer når de er ferdig med barnehagen, kan være et bidrag til en utjevning som på lang sikt blant annet bidrar til at for eksempel kvinneandelen på mastergradsstudenter $\mathrm{i}$ «computer science» kan bli høyere enn dagens $18 \%$.

At man på denne måten kan dempe digitale klasseskiller, må likevel ikke forstås som at det er slike instrumentelle grunner som først og fremst begrunner at barn bør bruke IKT i barnehagen. Rammeplanen for barnehagen sier at IKT skal være «en kilde til lek, kommunikasjon og innhenting av kunnskap» (Rammeplan for barnehagen, 2006, s. 21). IKT framstilles i Rammeplanen også som et instrument, men da som et instrument for barna der og da i barnehagehverdagen. At fornuftig bruk av IKT sammen med barna i barnehagen også kan ha andre positive og langsiktige virkninger utover barnehagehverdagen, vil ikke være noen ulempe.

Viktigere enn både reduksjon av digitale klasseskiller og at IKT skal være en kilde til lek, kommunikasjon og innhenting av kunnskap, er likevel hvordan dette gjøres i barnehagen. IKT er en besnærende teknologi som blant annet lett sluker brukerne, til fortrengsel for andre nødvendige aktiviteter i oppveksten. Med en gjennomtenkt pedagogikk fra barnehagepersonalets side kan barnehagen være en arena der barna lærer gode IKT-vaner, og være forbilder for foreldrene i deres IKT-oppdrageransvar. 


\section{LITTERATUR}

Adam, A. (2000). Feminist AI projects and cyberfutures. I G. Kirkup (red.), The Gendered Cyborg. A Reader (ss. 276-290). London ; New York: Routledge ; in association with the Open University.

Adam, A. (2005). Gender; Ethics and Information Technology. Basingstoke: Palgrave MacMillan.

Adam, A. (2008). The Gender Agenda in Computer Ethics. I K. E. Himma \& H. T. Tavani (red.), The Handbook of Information and Computer Ethics (ss. 589-619). Hoboken, NJ: Wiley.

Adam, A. (2010). Personal values and computer ethics. I L. Floridi (red.), The Cambridge Handbook of Information and Computer Ethica (ss. 149-162). Cambridge: Cambridge University Press.

Aseel, S. (2011). The effects of Computer Use on Creative Thinking among Kindergarten Children in Jordan. Journal of Instructional Psychology, 38, ss. 213-220.

Bergstrøm, I. I. (2014). Toril Moi: Feministisk teori trenger en revolusjon. Kilden Lastet ned fra http://kilden.forskningsradet.no/ c16880/artikkel/vis.html?tid $=89705$

Collins, P. H., \& Chepp, V. (2013). Intersecionality. I G. Waylen, K. Celis, J. Kantola \& S. L. Weldon (red.), The Oxford Handbook of gender and politics (ss. 57-87). Oxford: Oxford University Press.

Corneliussen, H. G. (2012). Gender-technology relations: exploring stability and change. Houndmills: Palgrave Macmillan.

Crenshaw, K. (1989). Demarginalizing the Intersection of Race and Sex: A Black Feminist Critique of Antidiscrimination Doctrine, Feminist Theory and Antiracist Politics. The University of Chicago Legal Forum, ss. 139-167.

Davis, K. (2011). Intersectionality as Buzzword:
A Sociology of Science Perspective on What Makes a Feminist Theory Successful. I H. Lutz, M. T. H. Vivar \& L. Supik (red.), Framing Intersectionality. Debates on a MultiFaceted Concept in Gender Studies (ss. 43-54). Surrey: Asgate.

Ess, C. (2009). Digital media ethics. Cambridge: Polity Press.

Feilitzen, C. v. (2010). Influences of mediated violoence. I U. Carlsson (red.), Children and youth in the digital media culture (ss. 173187). Göteborg: The international clearinghouse of children, youth and media.

Foucault, M. (1983). The Subject and Power (L. Sawyer, overs. Første gang utgitt 1982). I H. L. Dreyfus \& P. Rabinow (red.), Michel Foucault: Beyound Structuralism and Hermenutics (ss. 208-226). Chicago: University of Chicago Press.

Gilligan, C. (1982). In a different voice: psychological theory and women's development. London: Harvard University Press.

Gilligan, C. (2002). Med en annen stemme. Psykologisk teori og kvinners utvikling (M. Vestli, overs. Første gang utgitt 1982). Oslo: Gyldendal akademisk.

Hardersen, B., \& Guðmundsdottir, G. B. (2012). The Digital Universe of Young Children. Nordic Journal of Digital Literacy, 7, ss. 221-226.

Hartmann, T. (2013). Moral disengagement during exposure to media violence. I R. Tamborini (red.), Media and the moral mind (ss. 109-131). New York, London: Routledge.

Kirsh, S. J. (2010). Media and youth: a developmental perspective. Chichester: WileyBlackwell.

Ljung-Djärf, A. (2004). Spelet runt datorn: datoranvändande som meningsskapande praktik $i$ förskolan. (Doktorsavhandling i pedagogik, Malmö högskola, Malmö). 
Machiavelli, N., \& Bingen, J. (1998). Fyrsten. Oslo: Grøndahl Dreyer.

McKenney, S., \& Voogt, J. (2010). Technology and young children: How 4-7 years olds perceive their own use of computers. Computers in Human Behavior, 26, ss. 656-664.

Medietilsynet. (2014). Foreldre om småbarns mediebruk. Lastet ned fra http://www.medietilsynet.no/Documents/Barn\%20og\%20 medier-unders\%C3\%B8kelsene/Rapport Foreldre_smabarns_mediebruk_2014.pdf

Merton, R. K. (1968). The Matthew Effect in Science. Science, 159, ss. 56-63.

Moor, J. H. (2004). Reason, relativity, and responsibility in computer ethics. I T. W. Bynum \& S. Rogerson (red.), Computer ethics and professional responsibility (ss. 21-38). Malden, Mass.: Blackwell Publ.

Nikolopoulou, K., Gialamas, V., \& Batsouta, M. (2010). Young children's access to and use of ICT at home. Review of Science, Mathematics and ICT Education, 4, ss. 25-40.

Orupabo, J. (2014). Interseksjonalitet i praksis: Utfordringer med å anvende et interseksjonalitetsperspektiv i empirisk forskning. Sosiologisk tidsskrift, 22, ss. 329-351.
Rammeplan for barnehagens innhold og oppgaver. (2006). Kunnskapsdepartementet.

Sackes, M., Trundle, K. C., \& Bell, R. L. (2011). Young children's computer skills development from kindergarten to third grade. Computers \& Education, 57, ss. 1698-1704.

Sando, S. (2014). Barn, IKT og etikk. En studie $i$ digital etisk dannelse, med barnehagen som case. (Ph.D., Menighetsfakultetet, Oslo).

Store norske ordbok. (1991). Oslo: Kunnskapsforlaget.

Turner, E. (2006). Teaching Gender Inclusive Computer Ethics. I E. M. Trauth (red.), Encyclopedia of Gender and Information Technology (2 bind, ss. 1142-1147). Hersey, PA: Tdea Group Inc.

Tønnessen, E. S. (2007). Generasjon.com: mediekultur blant barn og unge. Oslo: Universitetsforlaget.

Weber, M. (1994). Makt og byråkrati (D. Østerberg, overs. Første gang utgitt 1922). Oslo: Gyldendal norsk forlag.

Winner, L. (1980). Do Artifacts Have Politics? Daedalus, 109, ss. 121-136.

Øgrim, T. (1997). Hilsen til en generasjon av kvikksølv! Oslo: Ziuzudra. 